\title{
ARTIGOS
}

\section{A ARQUITETURA EM ÁREA DE VIVÊNCIA DE CANTEIRO DE OBRAS: FATORES NORMATIVOS ASSOCIADOS À PERCEPÇÃO DO USUÁRIO LOCAL}

\section{THEARCHITECTUREIN CONSTRUCTIONSITES LIVING AREA:NORMATIVEFACTORSASSOCIATED WITH LOCAL USER PERCEPTION}

HELOISA NUNES E SILVA, M.SC. | UFSC JUAN ANTONIO ZAPATEL PEREIRA DE ARAÚJO, PhD. | UFSC

\begin{abstract}
RESUMO
Decorridos mais de 40 anos de aplicação da NR-18 no País, seu cumprimento pelas empresas construtoras ainda caminha para a consolidação. Neste sentido, as condições do ambiente construído da área de vivência da obra são tema de investigação nesta pesquisa, que busca reconhecer a condição desse ambiente construído à luz da Arquitetura e da legislação, bem como conhecer a opinião dos seus usuários sobre a atual condição da área de vivência e suas expectativas para o ambiente. Através da Avaliação Ergonômica do Ambiente Construído (MEAC) associada a parâmetros normativos (NR-18 e NBR 15.575) e de percepção ambiental pelo usuário, pela técnica da Constelação de Atributos, os dados obtidos indicam situações em desacordo legal, conflitos de acessibilidade e funcionalidade dos espaços, além de revelarem as características do ambiente construído ideal da área de vivência pelos usuários. Verificou-se que a Arquitetura mantém potencial de pesquisa científica em relação ao tema e lacunas profissionais sobre o projeto de edificações provisórias em canteiros de obras.
\end{abstract}

PALAVRAS CHAVE: Arquitetura; Canteiro de Obras; Habitabilidade; Área de Vivência

\begin{abstract}
After more than 40 years of application of the NR-18 in the country, its compliance by construction companies is still heading towards consolidation. In this sense, the conditions of the built environment of the sites's living area are the subject of investigation in this research, which seeks to recognize the condition of this built environment by the architecture and legislation, as well as to know the opinion of its users about the current condition of the living area and your building expectations. Through the Ergonomic Valuation of the Built Environment (MEAC) associated with normative parameters (NR-18 and NBR 15.575) and environmental perception by the user, using the Attribute Constellation technique, the obtained data indicate situations in legal disagreement, conflicts in accessibility and functionality of the spaces, besides revealing the characteristics. of the ideal built environment of the living area by the users. It was found that the Architecture maintains potential for scientific research in relation to the theme and professional gaps about the design of temporary buildings in construction site.
\end{abstract}

KEY WORDS: Architecture; Construction site; Habitability; Living Area 


\section{INTRODUÇÃO}

No canteiro de obras o viés produtivo da impera sobre esse espaço de trabalho da indústria da construção civil, que absorve a mão-de-obra de trabalhadores de distintas formações e em variados níveis de experiência profissional. Em 2019 o público envolvido na construção civil aproxima-se a 7\% da população empregada do Brasil, algo próximo de 6,5 milhões de pessoas, segundo dados do IBGE (2019).

Esse público usufrui diariamente de um espaço de trabalho em obras e transitório, segmentado entre área de produção (central de argamassas, área de formas e moldes ou carpintaria, etc) e área de vivência ( local de apoio com instalação sanitária, vestiários, refeitório,etc), com restrição em recursos materiais e de caráter de ambiente provisório (com tempo estimado de utilização). Tais características resultam em ambientes construídos baseados em baixo custo de investimento, adoção de tecnologias construtivas adequadas à temporalidade da obra e a cultura organizacional da empresa construtora, bom como num processo de planejamento da produção focado na otimização espacial do uso do terreno da obra.

No canteiro de obras o espaço disponível no terreno tem grande relevância, haja vista que a organização do layout da obra incide no ritmo da produção, bem como, no aspecto de funcionalidade da área de vivência da obra. A prioridade, em geral, está na linha de produção desta indústria que ocupa temporariamente um terreno, executa o produto (empreendimento) e depois desloca-se para outro local e inicia nova construção, e assim sucessivamente.

Considerado um espaço de trabalho de indústria, o canteiro de obras também segue legislações trabalhistas, em particular a Norma Regulamentadora (NR) n¹8 do Ministério do Trabalho (BRASIL,1978), cuja finalidade é de organizar as mínimas condições do ambiente de trabalho da indústria da construção civil. Tais indicativos da NR-18 associam temas de dimensionamento físico, tecnologias construtivas e características específicas dos ambientes requeridos para a obra.

Pode-se pontuar que essa norma inicia a abordagem sobre o conforto e a segurança do usuário no ambiente de trabalho, emergindo discussões quanto ao ambiente construído. Entretanto, essa norma carrega o viés da produtividade e da segurança dos processos da indústria de construção civil, sobrepondo-se a questões necessárias para embasar um ambiente construído confortável ao usuário.

Um ambiente construído é o resultado das considerações técnicas do projetista sobre fatores de uso/função, de insolação, de ventilação, de disposição/localização, de tecnologia construtiva, recursos financeiros, topografia, legislação, etc. Além disso, um ambiente construído carregar a capacidade de provocar sensações nos usuários, as quais são percebidas de maneira individualizada, gerando uma opinião sobre a qualidade daquele lugar. Ou seja, tanto as considerações técnicas quando as percepções do usuário sobre os ambiente construído são fatores que compõem o espaço vivenciado pelo homem, e isso é tema de Arquitetura, a ciência que trata dessa questões: projetar espaços para o homem habitar, inclusive em caráter provisório.

A Arquitetura associa fatores materiais e subjetivos no desenvolvimento de espaços para o homem, articulando novas situações /demandas ao processo de projeto de edificações. Entretanto, ela encontra-se distanciada do espaço do canteiro de obras, cuja aproximação é estreita à Engenharia Civil e à ótica industrial. É comum verificar o processo de projeto da área de vivência do canteiro de obras que enfatiza a lógica de adequação de linha de produção e da NR-18, e por outro lado, minimizando ou desconsiderando fatores da Arquitetura, como a insolação, a funcionalidade dos espaços, a avaliação do usuário sobre o ambiente construído.

Decorridos mais de 40 anos de aplicação da NR-18 no País, seu cumprimento pelas empresas construtoras ainda caminha para a consolidação e atualmente é motivo de revisão normativa. Neste sentido, as condições do ambiente construído da área de vivência da obra são tema de investigação nesta pesquisa, que busca reconhecer a condição desse ambiente construído à luz da Arquitetura e da legislação NR-18, bem como conhecer a opinião dos seus usuários sobre a atual condição da área de vivência e suas expectativas acerca dessa área de apoio da obra.

\section{FUNDAMENTAÇÃO TEÓRICA}

\subsection{O contexto da Arquitetura na Racionalização do Processo Construtivo}

Os edifícios podem ser reconhecidos de várias maneiras pela sociedade, por exemplo, como obras de arte, realizações técnicas, componentes do espaço urbano e também como espaços de fenômenos comportamentais e culturais (LAWSON, 2001). Objetivam acomodar o comportamento espacial humano. Para o autor, o espaço é um material essencial de uma forma universal de comunicação, e sua linguagem é observado por todos, embora tenha variações culturais. A Arquitetura organiza e estrutura o espaço para o homem a partir do uso da linguagem do espaço, resultando em facilitar ou inibir as atividades nesses locais. Sua relação com a racionalização compreende a atitude de controlar e definir um juízo em determinada situação durante o processo de projeto da edificação (GREGOTTI,1972; MONTANER,2014). 
O profissional arquiteto/engenheiro encontra uma variedade de técnicas construtivas e de insumos disponíveis na área da construção civil, e orienta ao cliente a opção que melhor atenda ao programa da edificação nos aspectos funcionais, técnicos e econômicos. Melhado (1994) aprofunda estudo sobre essa visão sistêmica sobre o processo racionalizado de projeto da edificação, focando sua discussão na apresentação de parâmetros desse processo aplicáveis tanto para a etapa de proposição do edifício (empreendimento) quanto para a etapa de produção, neste caso para o processo de elaboração do projeto do canteiro de obras.

A racionalização em arquitetura direciona-se ao processo de projeto do edifício, mais comumente relacionada ao empreendimento, sendo pouco usual sua contribuição à fase do canteiro de obras. Em ambas as situações há necessidade do processo de planejamento dos espaços construídos, considerando especificidades de clientes, localização, legislação, funcionalidade, tecnologia construtiva, conforto etc. Em relação a sua situação no Brasil, Fabricio (2013) observa esse distanciamento entre "produto e produção" como uma lacuna na contribuição científica da arquitetura, em que os canteiros de obras permaneceram manufaturas artesanais.

O sistema construtivo da construção civil no País apresenta dicotomias entre o produto (edifício) e a etapa de projeto da produção (no caso do canteiro de obras). Porém, ambos os processos de projeto envolvem um usuário definido e com demandas específicas, mas no caso do canteiro de obras ainda se mantém enuviadas, descaracterizadas ou inexploradas cientificamente. Existem iniciativas de outras área do conhecimento que contribuem cientificamente ao delinear melhorias no processo de execução da produção, tais como a gestão do processo de projeto, a aplicação de ferramentas tecnológicas para aumentar o desempenho da edificação, o controle e prevenção e perdas no processo. Entretanto, é escassa a temática que envolve a avaliação do ambiente construído em uso na etapa de produção do edifício, isto é, no canteiro de obras; desconhece-se a percepção do trabalhador sobre o ambiente construído do canteiro de obras e da área de vivência à luz dessa racionalização das construções.

\subsection{O Canteiro de Obras}

O A norma brasileira ABNT NBR 12.284 (1991) define canteiro de obras como "áreas destinadas à execução e apoio dos trabalhos da indústria da construção, dividindo-se em áreas operacionais (ex.: central de formas e moldes, central de argamassas,...) e áreas de vivência (ex.: instalações sanitárias, vestiários, refeitório, alojamento, área de lazer, ...)"
O espaço do canteiro de obras é habitado, logo possui características de ambiente construído (aspectos físicos de edificação) e de pessoas/usuários (aspectos subjetivos dos usuários do espaço) que necessitam ser identificados, reconhecidos e colocados em prática. Ferro \& Arantes (2006) comentam sobre o espaço do canteiro de obras durante a construção de Brasília/DF - entre 1958 a 1960, emergindo situações organizacionais de precariedade.

Considerando a indústria da construção civil brasileira com o uso de mão-de-obra como grande meio de produção (manufatureira), cada canteiro de obras possui pessoas trabalhando para construir edificações de diversos portes e em regiões variadas, e todos regidos pela mesma legislação que regulamenta a indústria da construção civil no País, a Norma Regulamentadora (NR) 18.

O espaço de trabalho da indústria da construção civil se caracteriza pelo canteiro de obras, um ambiente de trabalho sazonal e com diversas atividades além da de produção, entre elas a de moradia (trabalhador pode morar na obra por meio de alojamento), de lazer, de convívio social, de aprendizado, de circulação.

Tezel, Koskela \& Tzortzopoulos (2010) salientam que na indústria da construção, geralmente, as decisões são tomadas de cima para baixo, afetando toda a cadeia produtiva, onde ocorrem modificações pelos envolvidos, pois leva algum tempo para se modificar hábitos de trabalho convencionais. Além disso, Moreno \& Mamede (2013) relatam estudos de como o sistema construtivo em obras civis no Brasil, ainda é feito de maneira precária, com atrasos em obras, desperdício de materiais (TISAKA, 2011a: 2011b; MATTOS, 2006).

Saurin \& Formoso (2006) pontuam sobre conflitos no planejamento do canteiro de obras em que as decisões costumam ser tomadas à medida que os problemas surgem, no decorrer da execução. A partir disso os canteiros de obra muitas vezes refletem a inadequação em termos de organização ambiental - segurança do trabalho - qualidade de vida, fazendo com que, longe de criar uma imagem positiva nas empresas do mercado da construção civil, acabem por recomendar certa "distância".

Há uma condição peculiar na indústria da construção civil, onde o produto é fixo (edificação) e a linha de produção é móvel (operário é que se desloca) adaptada a cada empreendimento, refletindo em uma condição de ambiente construído intermitente (não é perene), além de ter um tempo estimado de "vida útil". Por isso, o canteiro de obras carece de investimento em seu ambiente construído, sendo muitas vezes improvisado ou adaptado ao tipo de edificação que se executa. Vários autores tratam sobre o processo de planejamento do espaço do canteiro 
de obras, como Rosso (1980), Melhado (1994), Ferreira \& Franco (1998) e Saurin \& Formoso (2006). Em linhas gerais, suas pesquisas abordam sobre a organização do espaço de produção da indústria da construção civil. Apresentam métodos de projeto do canteiro de obras considerando tipo de instalações que a obra requer, localização adequada e grau de conectividade entre estes elementos, etapas de evolução do canteiro de obras, sistemas construtivos e otimização de custos.

No Brasil, a Norma Regulamentadora (NR) - 18, Portaria 3.214 do MTE (BRASIL, 1978), trata sobre as "Condições e meio ambiente de trabalho na Indústria da Construção, estabelecendo diretrizes de ordem administrativa, de planejamento e de organização, que objetivam a implementação de medidas de controle e sistemas preventivos de segurança nos processos, nas condições e no meio ambiente de trabalho".

A norma apresenta uma lista de ambientes e de condições mínimas relacionados aos espaços de convivência do trabalhador, tendo cada ambiente requisitos específicos. Com isso busca-se dar as mínimas condições ambientais no espaço de trabalho de uma obra, independente do porte (pequena, média e grande) ou tipo (residencial, comercial, infraestrutura, etc) da construção, sendo válida e aplicada em todo o território nacional. Assim, os ambientes da área de vivência do canteiro de obras (vestiário, instalação sanitária, refeitório, cozinha, lavanderia, área de lazer) devem cumprir tais requisitos construtivos e em dimensão física (metragem construída), conforme apresentado no quadro 1.

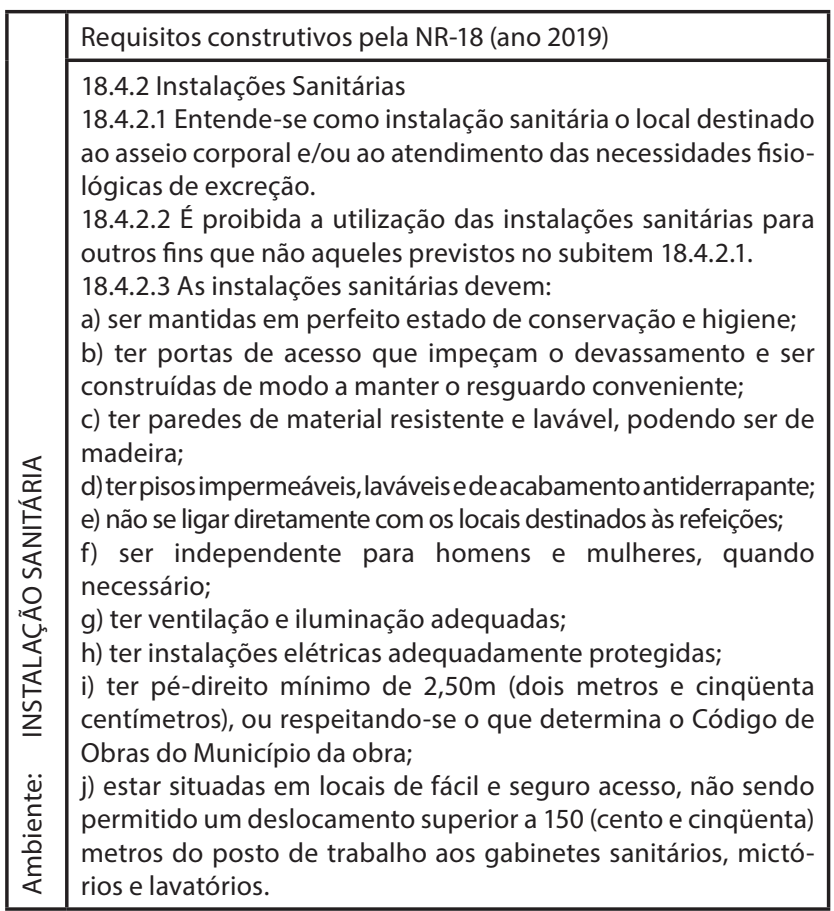

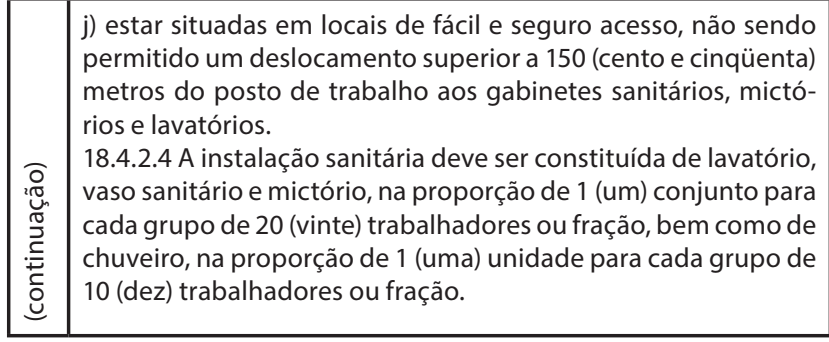

Quadro 1 - Exemplo de especificações para 0 ambiente de Instalação sanitária da área de vivência pela NR-18: 2019.

Fonte: NR-18 vigente em 2019, adaptado de Portaria 3.214 do MTE (1978).

Conforme dados do Ministério do Emprego (BRASIL, 2020), o cumprimento da NR-18 no País pelas empresas construtoras ainda caminha para a consolidação, tendo revisões normativas no decorrer dos tempos objetivando atualização de conteúdo às condições laborais. Em fevereiro de 2020 foi publicada NR-18 atualizada, compreende um modelo mais simplificado e de certa autonomia à empresa construtora em relação aos requisitos e critérios sobre a organização da área de vivência. Isso oportunizará novos estudos sobre a percepção ambiental do usuário diante de variadas soluções espaciais e de condições construtivas empregadas para a área de vivência.

E esta pesquisa foi realizada anteriormente à nova legislação, isto é, baseada na NR-18 em vigor no ano de 2019.

\subsection{Percepção do Ambiente Construído}

Tal como a moradia, o espaço de trabalho consiste num meio de interações entre pessoa-ambiente, sendo de forma peculiar devido às relações de apropriação espacial estabelecidas por cada indivíduo.

Segundo Lawson (2001), grande parte do comportamento do indivíduo no espaço envolve a comunicação de uma maneira ou de outra, isto é, de modo verbal ou não-verbal, sendo que nesta última envolve a percepção do espaço constituído. Essa "Linguagem do espaço", conforme denominado pelo autor, pode ser utilizada para vários propósitos, por exemplo: de expressar os valores e estilo de vida de uma empresa ou pessoa; de gerar sentimentos de excitação ou calma; de controlar a proximidade de outros indivíduos; de demonstrar domínio ou submissão na escala social; de comunicar a disposição e a forma de ser abordado e recebido; de aproximar as pessoas ou de mantê-las separadas; para transmitir regras de comportamento em locais públicos, privados, coletivos.

Nesse sentido, Daniel \& Ittelson (1981) relatam sobre pesquisas científicas envolvendo a percepção ambiental do espaço, cuja validade metodológica baseia-se primeiro numa abordagem direta acerca de características 
físicas / sociais relevantes aos estímulos no ambiente, e em segundo, no fato de utilizar uma métrica de avaliação de resposta do usuário que seja familiar ao repertório dos envolvidos no processo.

Okamoto (2002, p. 37-38) relata sobre o envolvimento do estudo do comportamento humano relacionado ao ambiente construído, a linguagem arquitetônica, significado e valores culturais dado ao espaço e meio ambiente, de modo que a reação aos estímulos ambientais origina, orienta e favorece a qualidade de vida do usuário. São os fatores de comunicação do ambiente construído (Figura 01) sendo: forma, função, cor, textura, aeração/ventilação, temperatura ambiente, significado simbólico, som e luz.

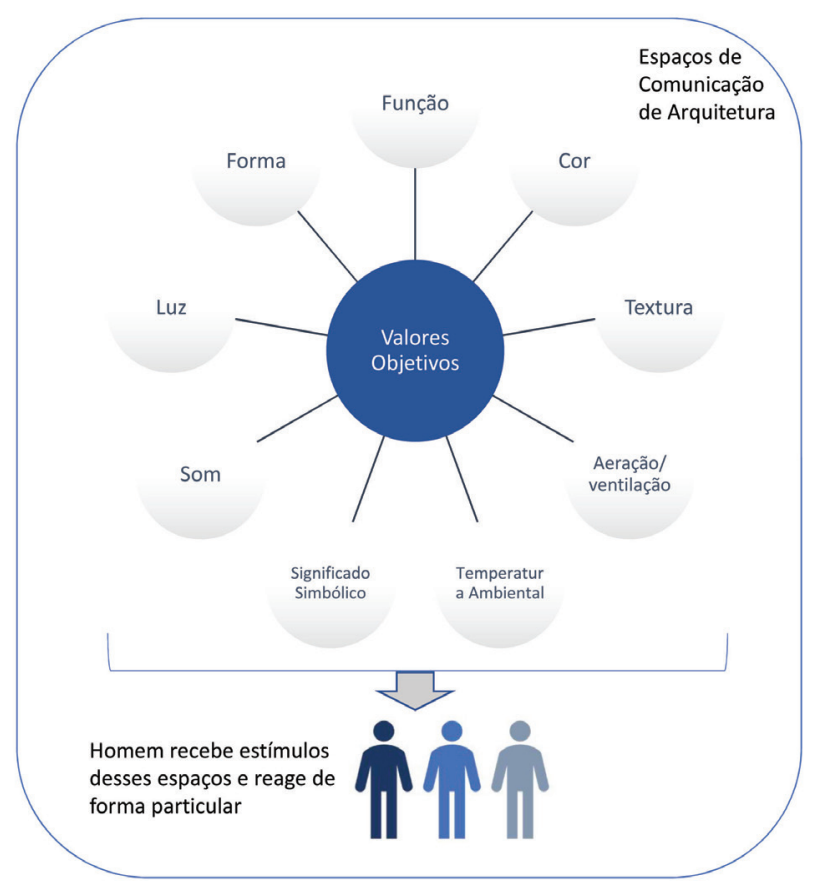

Figura 01 - Espaços de comunicação da Arquitetura no ambiente construído Fonte: Adaptado de Okamoto (2002).

Cada fator desses constitui-se num dado científico acerca de determinado grupo de pessoas e/ou de ambiente construído. Tal base de dados são orientativos para o processo de projeto do ambiente construído, pois reúne fatores de caráter pessoal e coletivo que impactam neste ambiente para o usuário final.

Segundo Elali e Pinheiro no artigo "Analisando a experiência do habitar: algumas estratégias metodológicas" (VILLA \& ORNSTEIN, 2013, p.18-35), a vivência num ambiente permite a criação de um elo afetivo que diferencia aquele lugar dos outros, caracterizando-o como especial, seja positivo ou negativo, e varia conforme as relações de interação social- individual ou grupal. O artigo discorre também sobre o comportamento socioespacial humano
(CSEH), por associar a nossa existência ao ambiente em que vivemos, o qual influencia o modo como interagimos em determinado ambiente, como na sala de aula, na praia, na moradia, no escritório.

Outro relato discutido naquele estudo é sobre as pessoas se adaptarem às condições do ambiente que vivenciam, podendo desenvolver visões menos críticas em relação ao local. Isto é, as pessoas utilizam estratégias próprias para adaptar o local aos seus anseios ou necessidades, mesmo que isso possa remeter a novas situações conflitantes no ambiente, porém é estabelecido um mecanismo cognitivo de aceitação das limitações advindas daquela transformação ambiental. Nesse sentido, pode haver uma diminuição das exigências ambientais e uma falsa sensação de adequação ao local pelo indivíduo.

No espaço de trabalho da construção civil, o ambiente construído possui características específicas de composição (layout, materiais, dimensão) para atender à demanda do espaço de trabalho, as quais podem interferir no modo de apropriação do ambiente pelos operários. Podem existir facilidades ou dificuldades em se vincular a pessoa ao ambiente construído, como no ambiente do refeitório da obra, cuja disposição de mesas pode resultar em uma sensação de exclusão ou inclusão ao lugar percebida pelo operário.

Compreende-se por espaço de trabalho o ambiente socio-físico em que o homem desenvolve artefatos materiais e intelectuais com propósito produtivo, induzido por um caráter de venda da sua capacidade laboral. Este espaço é constituído de características específicas, como um ambiente construído moldado à sua especificidade produtiva (fluxos, materiais, tecnologias), a coletividade de uso e a convivência grupal de pessoas, a delimitação do tempo de uso do ambiente (jornada de trabalho), a apropriação do ambiente pelas pessoas é diferenciada e constrita, além de orientações normativas sobre a organização e dimensão dos ambientes .

A complexidade que envolve o CSEH em ambiente de trabalho na construção civil necessita ser investigada para emergir a realidade do fenômeno da apropriação do ambiente construído para o trabalho pelo operário. A partir disso, pode-se estabelecer a capacidade dos ambientes da obra em atender as necessidades físicas e subjetivas dos operários, ou seja, capacidade de habitar do espaço de trabalho da obra

Sobre as necessidade subjetivas dos trabalhadores para a área de vivência, Saurin e Formoso (2006) apresentam de modo informal alguns fatos relacionados:

- Refeitório: "a inexistência ou as más condições de um ambiente devidoà falta de uso pelo funcionário(operário)... 
[...]...eles sentem vergonha de suas marmitas e de seus hábitos à mesa, preferindo fazer a refeição em locais diversos, sozinhos ou em pequenos grupos" (p.58);

- Área de Lazer: "exigida apenas quando houver alojamento, porém implementá-la mesmo quando não é aplicável a norma, pode se revelar uma iniciativa para aumentar a satisfação dos trabalhadores" (p. 60)

- Vestiário: " é o primeiro e o último local de uso dos operários no canteiro de obras, logo deve ser instalado próximo da entrada da obra, recomenda-se criar ligação coberta entre vestiário-portão...[...] deve ser próximo das instalações sanitárias, mas com acessos independentes... [...]...pode haver situações de furtos nos armários durante o expediente, e sugere-se instalar os chuveiros no vestiários, deixando os outros equipamentos para a instalação sanitária (caso, mictório, lavatório), de modo a tentar controlar mais o uso do ambiente e aumentar a sensação de segurança patrimonial" (p. 61) ....[...]...o mal cheiro da botinas após a jornada de trabalho faz com que estas sejam dispostas fora dos armários fechados, sugere-se a colocação de armário aberto para guarda e com identificação de usuário" (p. 62);

- Instalação Sanitária (Banheiro): " os chuveiros são locais de conflito, pois ao final do expediente podem gerar filas devido ao tempo de uso do operário, logo sugere-se considerar um número maior de unidades a serem instaladas...[...]...os vasos sanitários instalados para a administração da obra não devem ser computados com aqueles que serão de uso dos operários, pois não atendem aos requisitos da norma, bem como os sanitários volantes que servem para dar um apoio e comodidade a locais distantes na obra (tipo "banheiro químico")(p. 63)...a proximidade do banheiro com o vestiários, ao lado ou compartilhado no mesmo espaço, deve considerar os acessos de modo a manter a privacidade do operário, além de não se conectar diretamente com o refeitório"(p. 64)...as paredes adjacentes dos chuveiros devem possibilitar sua desinfecção, logo o uso de chapas de compensado (e madeira) devem receber revestimento protetor do tipo chapa galvanizada ou pintura impermeável"(p. 65).

A partir desses relatos, observa-se que as opiniões dos usuários impactam diretamente sobre o processo de projeto do canteiro de obras e do espaço de trabalho, pois indicam necessidade de alteração em requisitos materiais do ambiente construído.

\section{MÉTODOS DE PESQUISA}

A estrutura de pesquisa baseia-se na Metodologia Ergonômica de Avaliação de Ambiente Construído MEAC proposta por Villarouco (2008), em que o protocolo de observação é elaborado na pesquisa e possibilita o reconhecimento das condições do ambiente construído nos âmbitos físico-normativos e de percepção do usuário. Foi aplicado um estudo exploratório numa empresa de construção de edifícios em Criciúma/SC, na qual realizaram-se 4 estudo de caso em obras de construção de edifício de diferentes portes e com emprego de distintas tecnologias construtivas ( Figura 02).

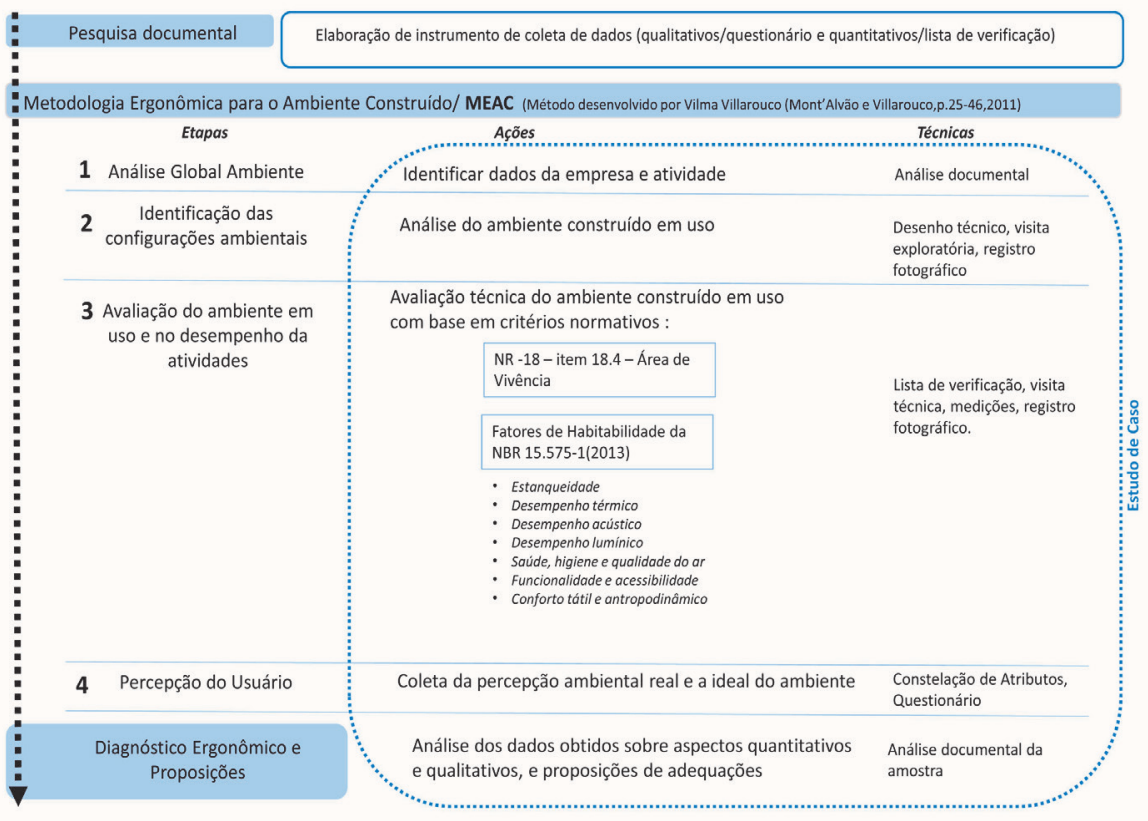

Figura 02 - Estrutura metodológica da pesquisa. Fonte: Autores, 2019 
Villarouco (2008) associa que partindo da necessidade de conjugação de metodologias de avaliação físicoespacial às ferramentas de identificação da percepção ambiental na aplicação das análises ergonômicas de ambientes construídos, a MEAC objetiva uma sistematização para análise do espaço, que repousa em elementos inegociáveis do olhar ergonômico, tais como o foco no usuário, a abordagem sistêmica e a usabilidade. A MEAC é compreendida em quatro etapas analíticas: 1) Análise Global do Ambiente, 2) Identificação da Configuração Ambiental, 3) Avaliação do Ambiente em uso no Desempenho das Atividades e 4) Percepção Ambiental. Por fim, contribui com o 5) Diagnóstico Ergonômico do Ambiente e Proposições.

As etapas 1,2 e 3 envolvem observação do ambiente construído, em que se utilizou técnicas de visita exploratória e de observação, registro fotográfico, lista de verificação específica por tipo de ambiente (Figura 03), desenho técnico (planta de layout e de implantação da área de vivência), medições (de nível de ruído, temperatura e iluminação através de aparelho Analisador de Ambiente Multi-funções: Decibelímetro -curva A(slow), Termômetro e Luxímetro, modelo THDL-400 / Instrutherm).

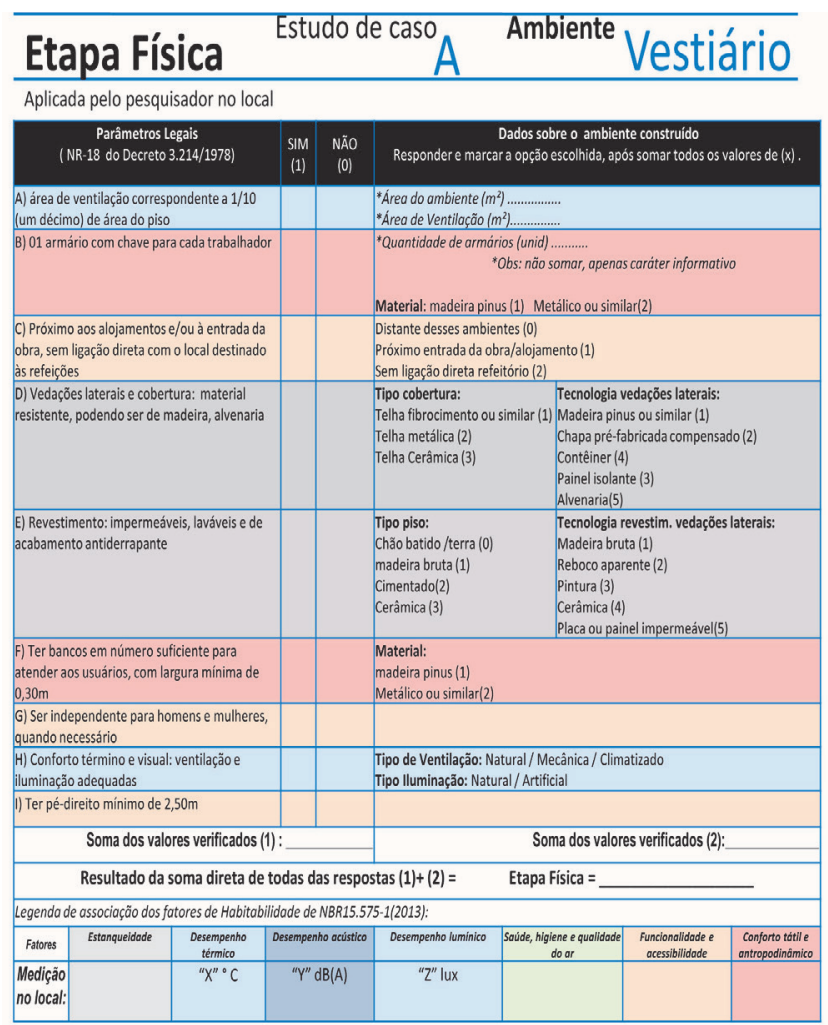

Figura 03 - Lista de verificação utilizada na pesquisa para ambiente Vestiário. Fonte: Autores,2019.

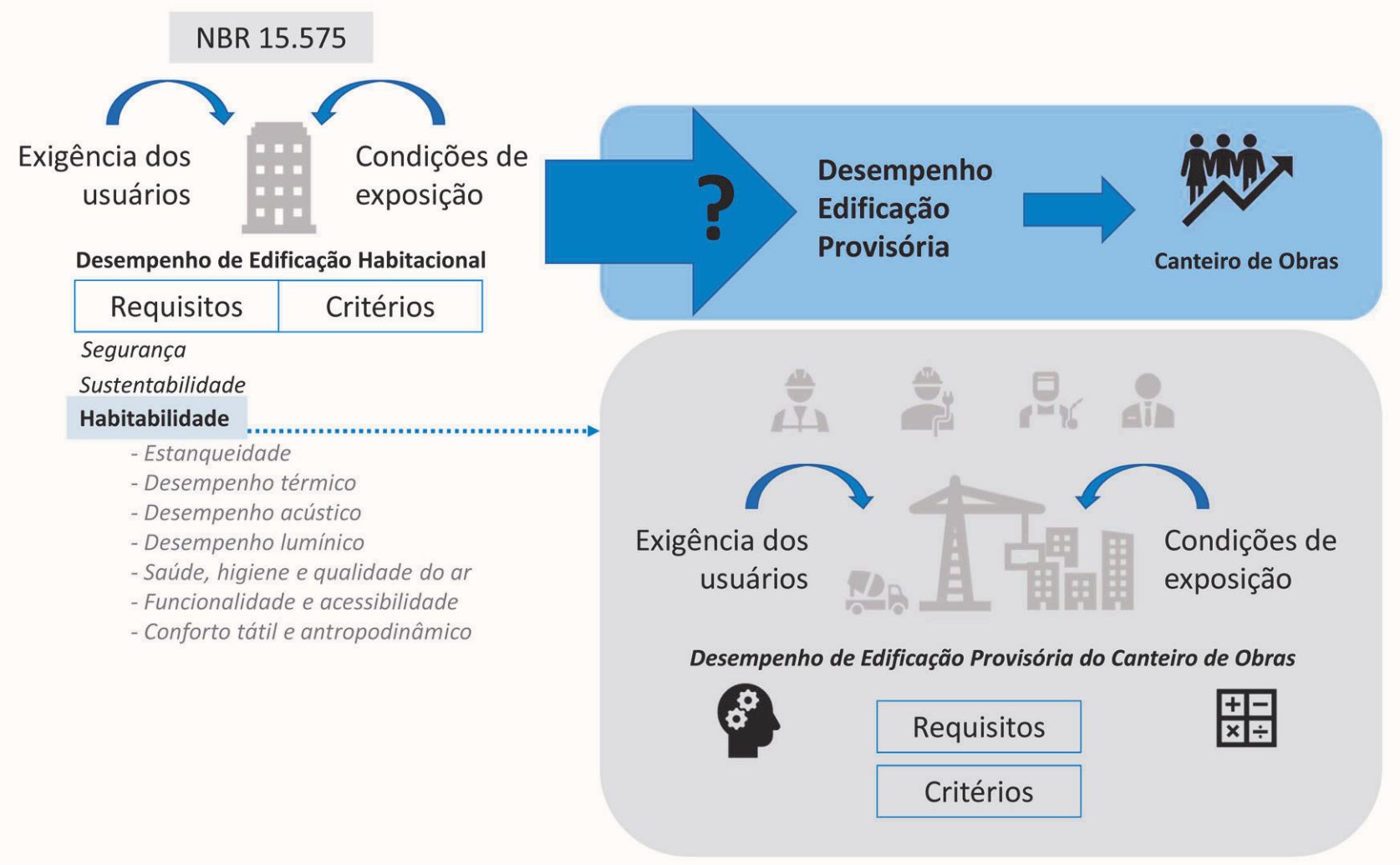

Figura 04 - Associação dos fatores de Habitabilidade da NBR 15.575(2013) ao itens estabelecidos pela norma NR-18.

Fonte: Autores, 2019 
O instrumento de lista de verificação foi elaborado pela pesquisa e associou a normativa da NR-18 (vigente até 2019) aos fatores de habitabilidade da Norma de Desempenho de Edificações - NBR-15.575-1(2013), com o objetivo de instrumentalizar a coleta de dados abrangendo os requisitos dimensionais, organizacionais e de ordem técnica da norma trabalhista e relacionando-os com os requisito de habitabilidade do ambiente construído (Figura 04), descrito na norma de desempenho em: Estanqueidade; Desempenho térmico; Desempenho acústico; Desempenho lumínico; Saúde, higiene e qualidade do ar; Funcionalidade e acessibilidade; Conforto tátil e antropodinâmico (disposição de pontos de comando e seu acionamento). Assim, essa pesquisa, expandiu a aplicação desses requisitos da norma de desempenho para ambientes construído provisórios, como no caso do canteiro de obras, objetivando iniciar um modo de avaliação do ambiente construído da obra pautado em modelo vigente e de reconhecimento científico. Essa avaliação da edificação provisória no canteiro de obras está relacionada com a capacidade de habitar que um ambiente construído possui. Neste caso, o termo habitar refere-se à condição do ambiente construído em permitir um indivíduo a vivenciá-lo, seja para trabalho ou lazer, onde ele tenha suas expectativas subjetivas e físicas atendidas.

$\mathrm{Na}$ etapa 4-Percepção Ambiental é considerada como fundamental na avaliação do espaço, por colocar o homem como personagem central de todas as ações. Segundo Villarouco (2008), não se pode conceber o estudo do ambiente construído sem a busca do entendimento da percepção do usuário acerca desse espaço, pois é ele de fato, o elemento que sofre mais de perto o impacto das sensações que o lugar pode transmitir. Esta etapa do trabalho consiste na identificação de variáveis de caráter mais cognitivo, através da aplicação e análise da Constelação de Atributo (MONTA'ALVÃO \& VILLAROUCO,2011) que tem por objetivo auxiliar no entendimento da percepção do usuário frente ao espaço por ele utilizado, em cuja construção do gráfico são utilizados procedimentos para avaliar a imagem simbólica do indivíduo frente ao ambiente e posteriormente, distinguir o que é objetivo do que é subjetivo na percepção do usuário.

A análise da percepção que o usuário tem do ambiente construído é realizada em duas etapas, nas quais busca-se identificar os atributos ligados à percepção do ambiente imaginário x real pelo usuário. Para tal, foram realizadas duas perguntas aos usuários: "O que vem a sua mente quando você pensa numa área de vivência do canteiro de obras?" e em seguida outra questão "O que vem a sua mente quando você pensa na área de vivência do canteiro de obras em que trabalha?". As respostas foram agrupadas conforme a similaridade das opiniões coletadas e categorizadas em aspectos de ambiente construído (relacionados com aspectos físicos do ambiente); organização (associado ao aspecto de organização cultural da empresa e de estrutura de trabalho) e social (relacionado ao aspectos socioculturais e afetivos dos usuários).

Acrescentou-se um terceira pergunta aos usuários, no intuito de coletar sugestões acerca do ambiente construído ideal para cada ambiente da área de vivência. Desse modo, pode-se verificar quais atributos foram mencionados e qual a frequência de repetições dentre a amostra.

Na etapa 5- Diagnóstico Ergonômico do Ambiente realiza-se a análise dos dados levantados e o confronto entre observações do pesquisador, das informações dadas pela empresa e dos dados da percepção dos usuários. São identificadas as situações positivas e negativas, os conflitos e os pontos fortes. Por fim, Proposições apresenta algumas recomendações de melhoria no local analisado, conforme uma visão sistêmica.

Esta pesquisa limita-se a área de vivência instalada nas obras estudadas, não considerada a área produtiva do canteiro de obras, bem como busca coletar a percepção do trabalhadores de cada obra, sejam terceirizados ou contratados da empresa.

\subsection{Estudo de Caso em Empresa de Construção de Edifícios}

O estudo de caso foi realizado na empresa "W" de construção civil da cidade de Criciúma/SC, a qual atua nesse ramo desde a década de 1990. A empresa utiliza um software de gerenciamento de obras civis, no formato de aplicativo para celulares, para gestão de dados de processo produtivo, de controle de custos, de aplicação normativa e legal, de segurança do trabalho e de gestão ambiental. Pesquisou-se em 4(quatro) obras de construção de edifícios, cuja caraterísticas são de diferentes etapas de execução, com variada tecnologia construtiva empregada na área de vivência de cada obra e de diversos portes de construção (pequeno, médio e grande). Dessa forma, ampliou-se a coleta da percepção do usuário sobre diferentes cenários de ambiente construído de área de vivência. Todas as visitas foram realizadas no mês de maio de 2019 em distintos períodos do dia, sendo realizado a inspeção técnica do ambiente construído da área de vivência na parte da manhã e na parte da tarde a coleta da percepção do usuário sobre o ambiente construído da área de vivência. 


\begin{tabular}{|c|c|c|c|c|}
\hline & Obra A & Obra B & Obra C & Obra D \\
\hline Local & Central & Periferia & Periferia & Periferia \\
\hline Bairro & Próspera & São Defende & Mina União & Santa Augusta \\
\hline Porte da obra & $\begin{array}{l}\text { Pequeno } \\
\text { (1 bloco) } \\
10 \text { pavimentos }\end{array}$ & $\begin{array}{l}\text { Grande } \\
\text { (18 blocos) } \\
4 \text { pavimentos }\end{array}$ & $\begin{array}{l}\text { Grande } \\
\text { ( } 25 \text { blocos) } \\
4 \text { pavimentos }\end{array}$ & $\begin{array}{l}\text { Médio } \\
\text { (4 blocos) } \\
9 \text { pavimentos }\end{array}$ \\
\hline Etapa da obra & Acabamento & Fundação / Alvenaria & $\begin{array}{l}\text { Fundação / Alvenaria / } \\
\text { Instalações / Revestimento } \\
\text { Acabamento }\end{array}$ & $\begin{array}{l}\text { Alvenaria/Instalações } \\
\text { / Revestimento/ } \\
\text { Acabamento }\end{array}$ \\
\hline Ambientes da Área de Vivência & $\begin{array}{l}\text { Vestiário, Instalação } \\
\text { sanitária, Refeitório }\end{array}$ & $\begin{array}{l}\text { Vestiário, Instalação sanitá- } \\
\text { ria, Refeitório }\end{array}$ & $\begin{array}{l}\text { Vestiário, Instalação } \\
\text { sanitária, Refeitório }\end{array}$ & $\begin{array}{l}\text { Vestiário, Instalação } \\
\text { sanitária, Refeitório }\end{array}$ \\
\hline $\begin{array}{l}\text { Tecnologia cons- } \\
\text { trutiva da área } \\
\text { de vivência }\end{array}$ & $\begin{array}{l}\text { Madeira bruta pintada, } \\
\text { placa metálica, telha } \\
\text { de fibrocimento }\end{array}$ & $\begin{array}{l}\text { Madeira bruta pintada, te- } \\
\text { lha de fibrocimento, alve- } \\
\text { naria rebocada, contêiner } \\
\text { (sanitários) }\end{array}$ & $\begin{array}{l}\text { Madeira bruta pintada, } \\
\text { telha de fibrocimento, } \\
\text { alvenaria rebocada, } \\
\text { contêiner (sanitários) }\end{array}$ & $\begin{array}{l}\text { Madeira bruta } \\
\text { pintada, placa } \\
\text { metálica, telha de } \\
\text { fibrocimento }\end{array}$ \\
\hline Número operários & 20 & 50 & 110 & 60 \\
\hline Participantes na pesquisa & 14 & 34 & 83 & 38 \\
\hline $\begin{array}{l}\text { Tempo médio de profissão na } \\
\text { construção civil dos trabalha- } \\
\text { dores (anos) }\end{array}$ & 16,17 & 5,81 & 8,99 & 10,85 \\
\hline
\end{tabular}

Tabela 01 - Informações sobre as obras pesquisadas na empresa "W".

Fonte: Autores, 2019.

\section{RESULTADOS E DISCUSSÕES}

\subsection{Análise Global do Ambiente}

Em todas as 4 obras analisadas existiam os ambientes de vestiário, instalação sanitária e refeitório, variando a localização do terreno, a técnica construtiva empregada na área de vivência, o layout adotado no canteiro de obras e o público de trabalhadores em obra. A seguir, (Figura 05) algumas observações de cada obra:

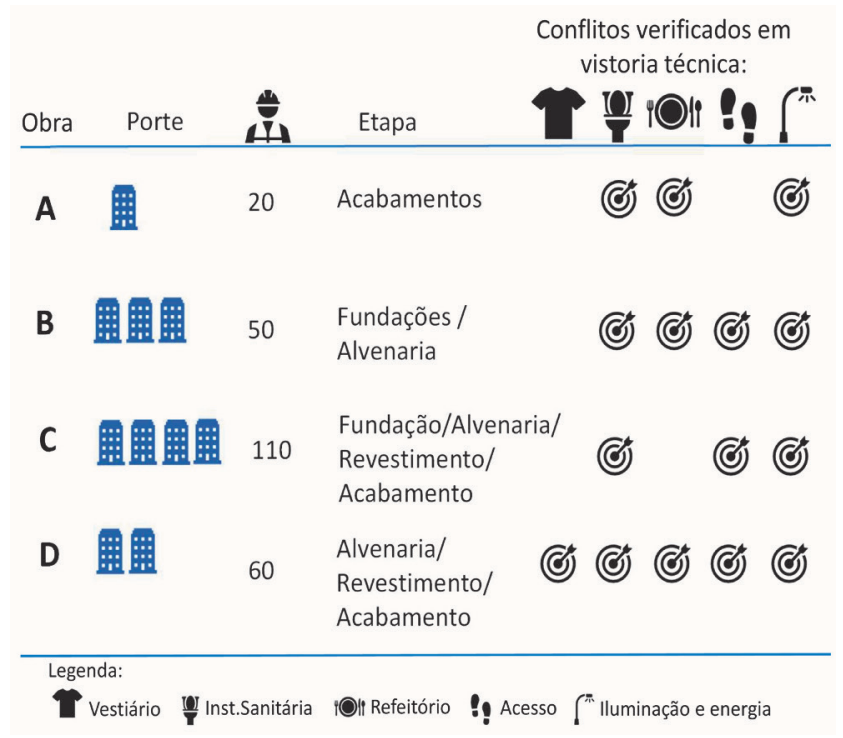

Figura 05 - Síntese de conflitos observados na vistoria técnica. Fonte: Autores, 2019.

\subsection{Identificação das Configurações Ambientais (Etapa Física)}

Os dados levantados pela lista de verificação da etapa física nas obras foram organizados em relação ao tipo de ambiente, sendo apresentados a seguir:

\subsubsection{Vestiário}

Em relação ao dimensionamento do ambientes e equipamentos instalados, segundo orienta a NR-18, o espaço organizado da obra $A$ atendeu a todos os requisitos normativos, sendo que a obra $D$ deixou de atender um item apenas (número de banco) e as obras B e C apresentaram descumprimento de dois itens cada uma (área de ventilação insuficiente/B-C e número de banco/B e armário individual/C) (Figuras 06 e 07).

O layout adotado nas obras comporta armários e banco, com circulação adequada, porém nas obras A e D o espaço não comporta a presenta de todos os trabalhadores ao mesmo tempo, sendo o uso na forma de rodízio. Em todos os ambientes de vestiário a ventilação era natural, porém mantinha-se a presença de odores de vestuários e calçados usados. Na obra B havia uma estante para guarda de itens diversos e de livre acesso do usuário, facilitando a guarda de objetos pessoais além do armário individual. $O$ aspecto geral do ambiente era de organizado e nas obras $B$ e D os ambientes eram mantidos fechados a chave, sendo controlado o uso. 


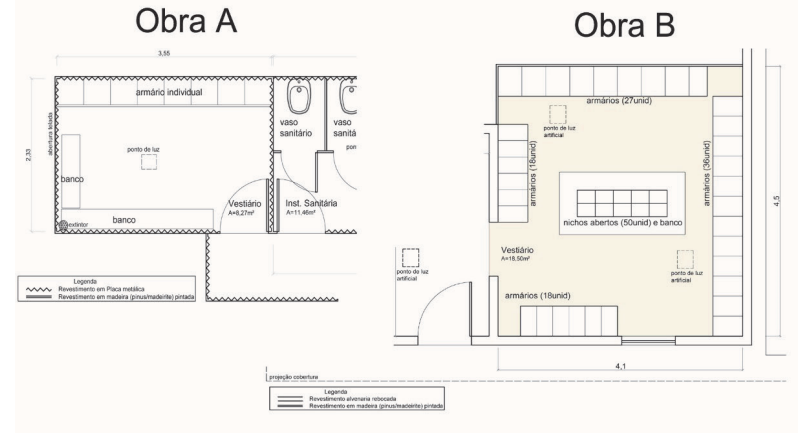

Figura 06 - Layout do Vestiário das obras A, B, C e D. Fonte: Autores,2019.

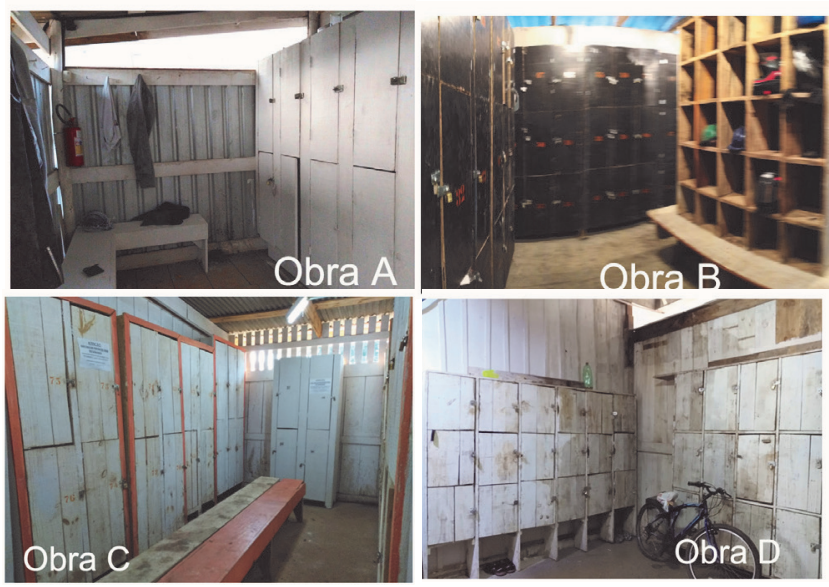

Figura 07 - Foto do ambiente de vestiário das obras A, B, C e D. Fonte: Autores,2019.

A tecnologia construtiva predominante era a madeira (roliça e réguas), com piso cimentado e cobertura aparente em telha de fibrocimento. As vedações laterais eram em madeira na sua maioria, tendo uso de chapa metálica na obra A e de alvenaria rebocada na obra $B$.

Havia infiltrações de água pelo teto na obra D (moIhando os armários individuais), gerando poças de água no piso do ambiente, prejudicando o uso do espaço.

O conforto térmico do ambiente era adequado ao clima no período da pesquisa (final do outono), com temperaturas internas entre $20^{\circ}$ a $17^{\circ} \mathrm{C}$. O conforto acústico no vestiário das obras obteve medições abaixo do limite de $85 \mathrm{~dB}(\mathrm{~A})$, estando de acordo com as normas regulamentadoras (NR-15).

Em relação ao conforto lumínico nos vestiários foram identificadas situações de pouca influência da iluminação natural (pequenas aberturas por onde há a circulação de ar) e falta de intensidade da iluminação artificial, cujas medições revelaram baixa iluminação nos espaços (valores medidos de 20 lux a 60 lux) e em desacordo com a orientação das normas regulamentadoras (NR-24 indica no mínimo de 100lux no ambiente).
Sobre a saúde, higiene e qualidade do ar, os ambientes estavam adequados, da mesma maneira o conforto tátil e antropodinâmico. A funcionalidade e acessibilidade dos ambientes apresentaram conflitos em relação à distância a instalação sanitária e a falta de barreira na porta de entrada para a manter a privacidade no ambiente em uso. Apenas a obra A dispunha de anteparo na porta de entrada e era justaposta a instalação sanitária.

\subsubsection{Instalação Sanitária}

Em relação ao dimensionamento do ambientes e equipamentos instalados, segundo orienta a NR-18, todas as obras descumprem as orientações sobre a área de chuveiros (área mínima para os boxes individuais e instalação de suporte de sabonete e toalha). Outra inadequação foi que metade das obras não dispõem do total necessário de lavatórios instalados no ambiente.

Os layouts adotados para o ambiente eram parecidos, tendo uma ala para vasos sanitários/mictório/ lavatórios e outra para ala de chuveiros coletivos. Nas obras $B$ e $C$ eram utilizados containers adaptados a instalações sanitárias, sendo nas obras $A$ e $D$ um espaço provisório construído em madeira. A circulação interna nos ambientes era restrita a pouco espaço, podendo haver conflitos entre usuários no uso da circulação, bem como a porta de acesso aos chuveiros invadia o box de um chuveiro, invalidando seu uso efetivo além de expor a privacidade dos usuários no local. A obra $D$ adotou a separação interna entre essas alas, cujos acesso eram independentes e sem tratamento externo (contato direto com o solo/lama). Nas obras C e D verificou-se o número insuficiente de lavatórios disponíveis (C: existiam 4 unidades para 110 trabalhadores; D havia 2 tanques para 60 trabalhadores), em que o indicado pelo NR-18 é na proporção de 1 lavatório para cada 20 trabalhadores (Figura 08 e 09). 


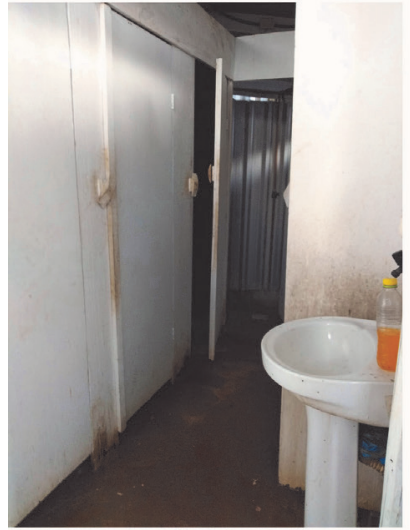

Obra A

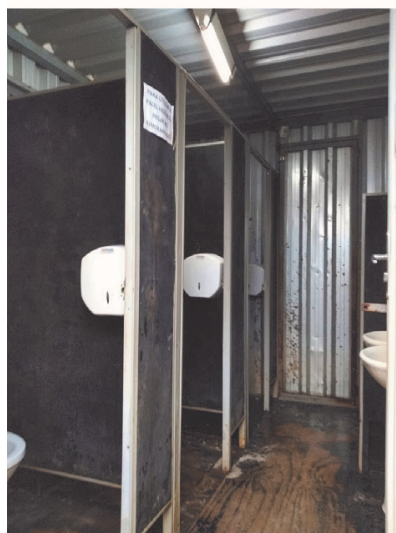

Obra C

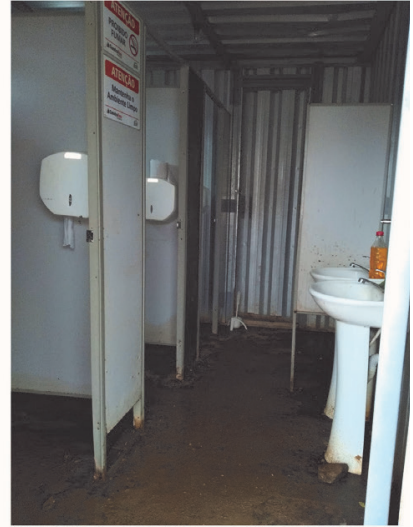

Obra B

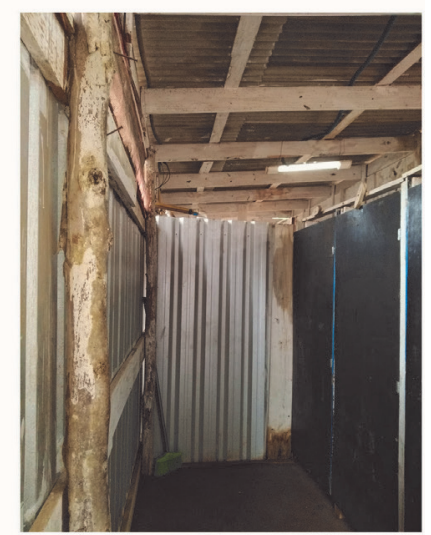

Obra D
Figura 08 - Fotos da Instalação Sanitária das obras A, B, C e D. Fonte: Autores, 2019 .
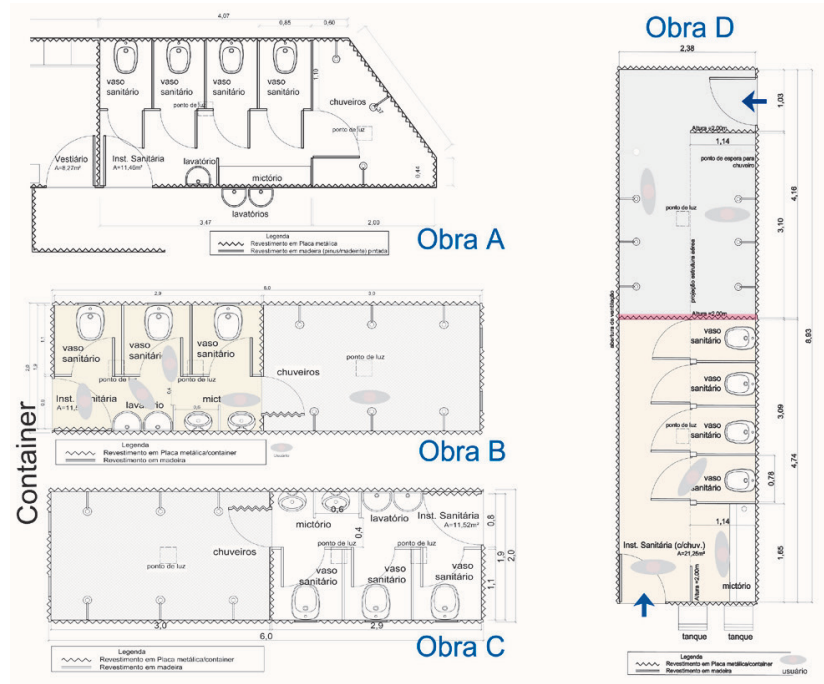

Figura 09 - Layout das instalações sanitárias das obras A, B, C e D. Fonte: Autores, 2019.

A tecnologia construtiva encontrada em metade das obras era a madeira (roliça e réguas), com piso cimentado e cobertura aparente em telha de fibrocimento, sendo a outra metade em módulo container adaptado para uso sanitário.
O conforto térmico do ambiente era adequado ao clima no período da pesquisa (final do outono), com temperaturas internas entre $20^{\circ}$ a $17^{\circ} \mathrm{C}$.

O conforto acústico no vestiário das obras obteve medições abaixo do limite de $85 \mathrm{~dB}(\mathrm{~A})$, estando de acordo com as normas regulamentadoras (NR-15).

Em relação ao conforto lumínico foram identificadas situações de pouca influência da iluminação natural (pequenas aberturas por onde há a circulação de ar) e falta de intensidade da iluminação artificial, cujas medições revelaram baixa iluminação nos espaços (valores medidos de 20 lux a 80 lux) e em desacordo com a orientação das normas regulamentadoras (NR-24 indica no mínimo de 100lux no ambiente).

Sobre a saúde, higiene e qualidade do ar, os ambientes estavam adequados, da mesma maneira o conforto tátil e antropodinâmico. A funcionalidade dos ambientes apresentou conflitos em relação à distância até o vestiário e a falta de barreira na porta de entrada para a manter a privacidade no ambiente em uso. E em geral, sem caminho tratado (solo natural/lama), prejudicando a acessibilidade e funcionalidade entre eles.

\subsubsection{Refeitório}

Em relação ao dimensionamento do ambientes e equipamentos instalados, segundo orienta a NR-18, metade das obras cumpre integralmente a legislação, sendo que as outra parte descumpre um item da norma (B: pé-direito em desacordo; C: inexistência de bebedouro no refeitório) (Figuras 10 e 11).

O layout adotado em metade das obras é adequado ao espaço da edificação permanente, com restrições de mudanças (obra A e B), e na outra parcela os espaço foram construídos provisoriamente (obras C e D), cuja planta baixa é ampla e localizada na periferia do terreno.

Os espaços comportam os trabalhadores na modalidade de turnos de refeição, sendo também locais de capacitações e de lazer/descanso. Na obra a não havia esquadria instalada na abertura da parede, em que o contato das intempéries prejudica o uso das mesas/cadeiras, além de não haver ponto de iluminação artificial ativo. $\mathrm{Na}$ obra $\mathrm{D}$ a proximidade do refeitório com o bloco de edifícios em execução gerou problemas de queda de materiais no telhado do refeitório, provocando infiltrações em dias de chuva que atingem a todo o espaço de refeição e prejudica a sua funcionalidade.

A tecnologia construtiva predominante era a madeira (roliça e réguas), com piso cimentado e cobertura aparente em telha de fibrocimento. As vedações laterais eram em 
madeira na sua maioria, tendo uso de alvenaria rebocada na obra $\mathrm{A}$. O conforto térmico do ambiente era adequado ao clima no período da pesquisa (final do outono), com temperaturas internas entre $20^{\circ}$ a $17^{\circ} \mathrm{C}$.

O conforto acústico no vestiário das obras obteve medições abaixo do limite de $85 \mathrm{~dB}(\mathrm{~A})$, estando de acordo com as normas regulamentadoras (NR-15). Em relação ao conforto lumínico nos refeitórios foram identificadas situações de pouca influência da iluminação natural (aberturas) e falta de intensidade da iluminação artificial, cujas medições revelaram baixa iluminação nos espaços (valores medidos de 20 lux a 47 lux) e em desacordo com a orientação das normas regulamentadoras (NR-24 indica no mínimo de 100 lux no ambiente). Apenas a obra A cumpre a legislação, devido ao grande espaço da abertura da parede sem esquadria instalada, pois no local não havia ponto de iluminação ativo.

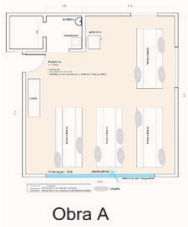

Obra A

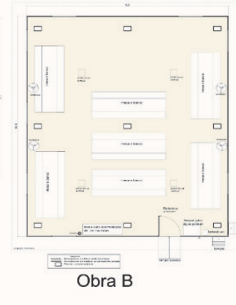

Obra C
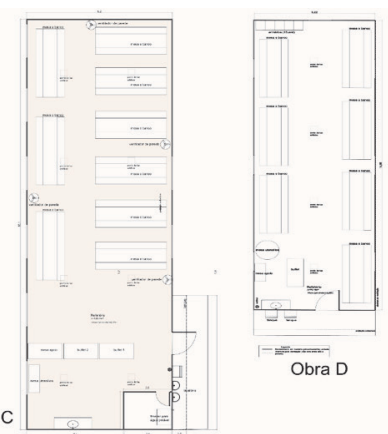

Figura 10 - Layout do Refeitório das obras A, B, C e D. Fonte: Autores,2019.

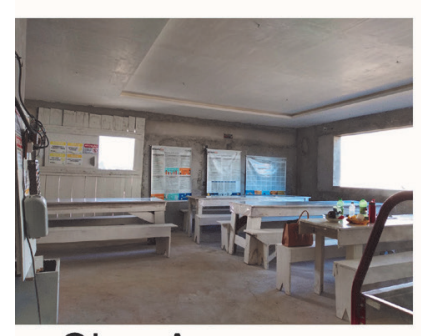

Obra A

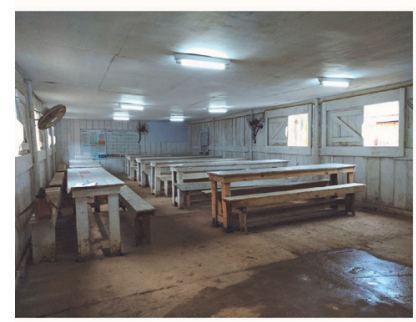

Obra C

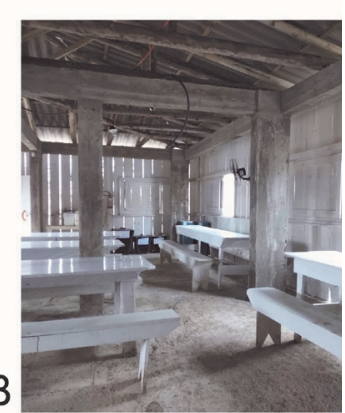

Obra B

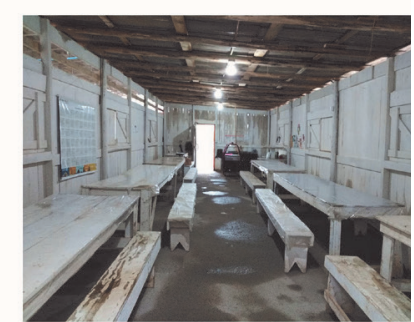

Obra D
Figura 11 - Fotos do ambiente de refeitório das obras A, B, C e D. Fonte: Autores, 2019.
Sobre a saúde, higiene e qualidade do ar, os ambientes estavam adequados, da mesma maneira o conforto tátil e antropodinâmico. A acessibilidade dos ambientes apresentou conflitos em relação ao caminho sem tratamento (solo natural/ lama), sendo que apenas a obra A e $D$ possuíam caminhos adequados (cimentado/pedrisco).

\subsection{Avaliação do Ambiente em uso no Desempenho das Atividades}

A seguir são apresentadas as situações verificadas acerca do layout, de fluxos e das condições ambientais analisadas nas obras.

\subsubsection{Fluxo Entre Vestiário XInstalação Sanitária}

$O$ conflito de relação entre $o$ ambiente do vestiário $x$ instalação sanitária prevalece na maioria das obras analisadas. Eles estão localizados em pontos distantes do terreno e alguns afastados da entrada da obra, geralmente necessário cruzar a circulação geral da obra para acessar um dos locais, em meio ao trânsito de maquinários e de solo lamacento. Isso ocorre nas obras B, C e D, em que as distâncias percorridas pelo usuário entre esses ambientes podem variar entre 40 metros a 170 metros, em caminhos sem tratamento (direto solo/lama) (Figura 12). Esse layout é resultante da forma com que cada gestor de obra organiza a locação da obra e dos espaços resultantes para acomodar a área de vivência.

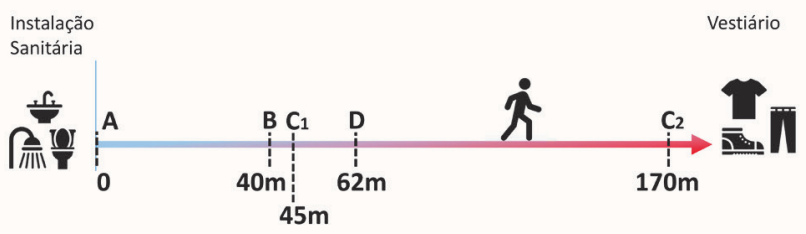

Figura 12 - Relação do percurso entre o vestiário a instalação sanitárias nas obras A, B, C e D. A obra C possui dois ambientes de instalação sanitária (C1 e C2).

Fonte: Autores,2019.

A obra $C$ possui dois containers de instalação sanitária distribuídos pela obra, objetivando facilidade de acesso, sendo um no meio da obra e outro nas proximidade do refeitório. Disso, resulta num trajeto entre a instalação sanitária do meio da obra até o vestiário no percurso estimado em 170 metros por caminhos de lama e em meio a circulação de veículos pesados. A obra A possui a situação ideal em que os ambientes de vestiários e instalação sanitárias estão lado a lado e com caminho tratado (cimentado), além de estarem localizado na entrada da obra. 


\subsubsection{Layout}

A área de vivência foi organizada pelo setor de engenharia da empresa $\mathrm{W}$, conforme a área disponível no terreno após locação da construção e da definição da área de produção. Isso gerou um fator de adaptação do espaço da área de vivência naquilo que é viável executar e segundo os preceitos normativos da NR-18 (Figura 13).

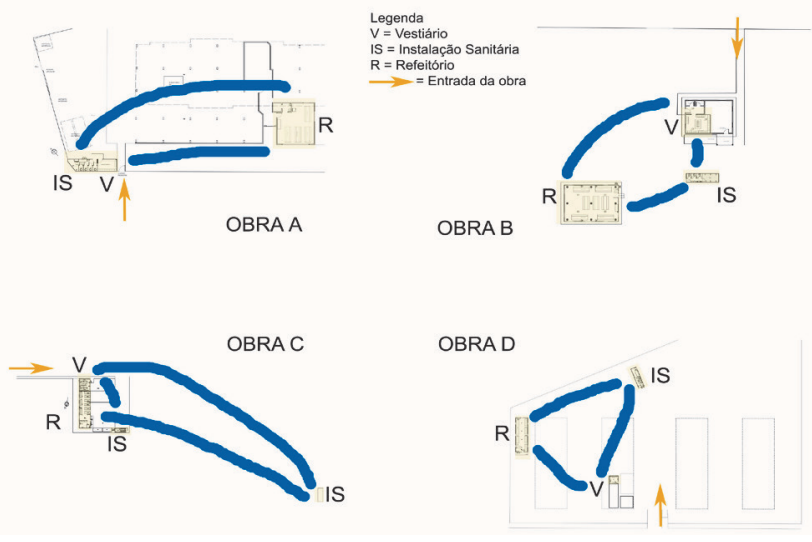

Figura 13 - Layout da área de vivência instalada nas obras A, B, C e D. Fonte: Autores, 2019.

Em relação ao layout dos ambientes da área de vivência, observou-se que as instalações sanitárias das obras $A, B$ e $C$ apontaram maiores conflitos por terem pouco espaço de circulação e ainda de esta acumular duas funções (de circulação e de área de mictório/lavatório), além de adotar o uso do chuveiro coletivo com problema de falta de privacidade e de a porta do local atrapalhar a área privativa de um box de chuveiro (Figura 14).

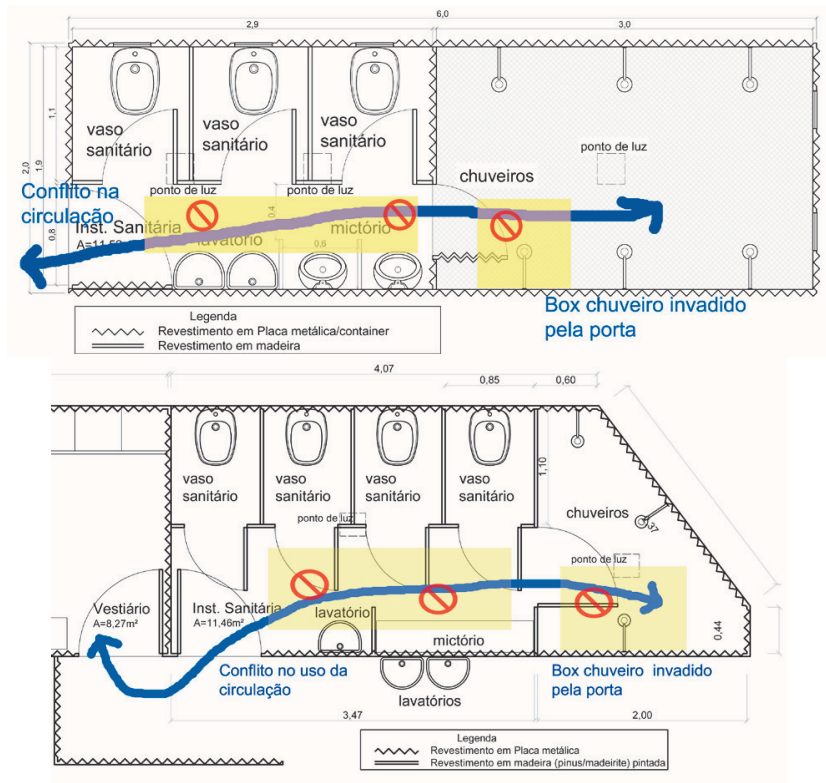

Figura 14-Conflitos de layout da instalação sanitária em contêiner (B, C) eem edificação de madeira (A). Fonte: Autores,2019.
O layout do vestiário e do refeitório estavam adequados, mesmo com a estratégia de rodízio do uso pelos funcionários, permitida pela NR-18.

\subsection{Percepção Ambiental (Etapa Subjetiva)}

A partir da participação voluntária de 169 trabalhadores das obras visitadas, coletaram-se dados sobre percepção do ambiente construído da área de vivência, orientados em relação ao ambiente ideal (imaginário) e ao ambiente atual em uso (real), através de questionário anônimo, obtendo o total de 146 respostas válidas, representando $86 \%$ da amostra. Cada resposta dada pelo usuário é um atributo sugerido ao ambiente, de modo que quanto maior a frequência com que ele aparece, maior é a sua relevância para a amostra.

A análise dos dados obtidos expõe que a percepção ambiental dos usuários da amostra sobre a área de vivência existente no seu atual local de trabalho (ambiente real), segundo as categorias de análise com maior frequência de citações:

- Ambiente: bom, tranquilo, confortável, atende sua função (40); local com segurança do trabalho (8); espaço um pouco apertado, poderia ser maior (4); vestiário amplos para acomodar melhor as pessoas(3); bom ambiente para trabalhar(3); circulação com muita lama(3); ambiente composto de cozinha, refeitório, inst.sanitária, vestiário(3); indiferente na avaliação, pois só pensa no trabalho(3); vestiário com(2) e pequeno(2); ambiente de lazer(2) e local que todos precisam de segurança para desempenhar seu trabalho(2);

-Organização: local organizado e limpo (41); satisfeito com a área atual (4); organização razoável(2); respeitar normas e ter cuidado com o espaço(2); melhorar a organização(2), muito trabalho(2) e máquinas e ferramentas boas(2);

-Social: trabalho em equipe (4); ambiente de respeito entre as pessoas (3) e sente-se feliz no local de trabalho (2).

No contexto geral da amostra sobre percepção do ambiente real, foram relatados mais atributos para a categoria ambiente totalizando $54,55 \%$, e a categoria social obteve a menor parcela de $10,23 \%$ das citações dos atributos. Verificou-se o relato de várias percepções distintas e com apenas uma citação que apontam para situações específicas no ambiente avaliado, tais como: pouco espaço no box do vaso sanitário, vestiário pequeno e sem barreira de privacidade na porta, sanitário longe da produção, colorido, etc. Entretanto, essas contribuições individualizadas ampliam a análise da percepção do ambiente por revelarem situações particularizadas, fato que permite a reflexão no processo de projeto da área de vivência a partir de dados atualizados do público que vivência esse ambiente construído. 
No que se refere aos dados coletados sobre a percepção do ambiente ideal da área de vivência (ambiente imaginário) os atributos relatados de maior frequência na amostra são:

- Ambiente: espaço grande (14), espaço com acesso ruim devido à lama(10), refeitório(7), local bom para trabaIhar(5), ter os ambientes vestiário/refeitório/inst.sanitária (5), inst.sanitária (4), indiferente (4), área boa(3), local seguro (3), ponto de apoio(3), local confortável (3), vestiário(2), ambiente adequado (2), com água potável e banheiros(2);

-Organização: higiene/limpeza/organização (52), espaço de trabalho profissional e em equipe (3), espaço importante e obrigatório em obra (3), utilizar local com segurança (3), boa comunicação/sinalização (2), área com atenção aos riscos (2);

- Social: local que a pessoa se sente muito bem(5), segurança/respeito /ética(5), representa a segunda casa da pessoa(5), local de amizade(4), local de trabalho que todos se ajudam(3), local de convívio de diferentes pessoas(2).

Observou-se que as atribuições apontadas na amostra sobre o ambiente imaginário da área de vivência tiveram incidência próximas entre as categorias ambiente
$(42,47 \%)$ e organização $(41,40 \%)$ e a menor verificação foi na categoria social $(16,13 \%)$. Também foram constatados relatos de apenas uma citação, evidenciando sugestão de melhoria numa determinada situação, tais como: local de apoio/descanso na hora do intervalo do almoço, mais vasos sanitários/lavatórios/chuveiros, lugar cheio e apertado, localização mais perto da produção, etc.

Sobre as contribuições coletadas acerca de como seria o ambiente construído ideal de cada um dos 7 espaços da área de vivência, verificou-se que o ambiente com maior número de atributos sugeridos pelos participantes (Quadro 02$)$ foi o vestiário $(26,10 \%)$, seguido pelo refeitório $(22,48 \%)$ e pela instalação sanitária $(18,87 \%)$. Isso ocorre pela maior relação de uso diário com esses ambientes e sua constante observação acerca de situações de desconforto vivenciada nesses espaços. Em contraste com os menores valores verificados para ambientes de lavanderia $(6,29 \%)$, área de lazer (8,18\%), alojamento $(8,49 \%)$ e cozinha $(9,59 \%)$, os quais indicam não haver uma relação de prioridade de uso e apropriação do espaço para o público pesquisado.

QUANTIDADE DE ATRIBUTOS AO AMBIENTE

\begin{tabular}{|c|c|c|c|c|c|c|}
\hline \multicolumn{7}{|c|}{ QUANTIDADE DE ATRIBUTOS AO AMBIENTE } \\
\hline CATEGORIAS & OBRA A & OBRA B & OBRA C & OBRA D & total & (\%) \\
\hline ALOJAMENTO & 7 & 22 & 20 & 5 & 54 & $8,49 \%$ \\
\hline ÁREA DE LAZER & 11 & 14 & 21 & 6 & 52 & $8,18 \%$ \\
\hline COZINHA & 11 & 16 & 31 & 3 & 61 & $9,59 \%$ \\
\hline IINSTALAÇÃO SANITÁRIA & 12 & 36 & 42 & 30 & 120 & $18,87 \%$ \\
\hline LAVANDERIA & 6 & 15 & 18 & 1 & 40 & $6,29 \%$ \\
\hline REFERITÓRIO & 17 & 32 & 64 & 30 & 143 & $22,48 \%$ \\
\hline VESTIÁRIO & 24 & 42 & 62 & 38 & 166 & $26,10 \%$ \\
\hline TOTAL DE RESPOSTAS & 88 & 177 & 258 & 113 & 636 & $100 \%$ \\
\hline TOTAL DE ENTREVISTADOS & 13 & 32 & 65 & 36 & 146 & -- \\
\hline
\end{tabular}

Quadro 02 - Síntese de dados coletados sobre atributos do ambiente ideal para área de vivência individualizado por local. Fonte: Autores,2019.

$\mathrm{Na}$ análise individual dos ambientes, os dados coletados foram diferenciados por tipo de ambiente da área de vivência, bem como sua quantidade de citações, e de dois contextos associativos em que o primeiro relaciona-se com os fatores de habitabilidade da NBR 15.575 (2013), e o segundo com a classificação em categoria ambiente, organização ou social. A partir disso, observou-se que a maioria do atributos verificados na amostra $(78,33 \%)$ estão diretamente relacionados aos Fatores de Habitabilidade de uma edificação construída. E verificou-se que a maioria dos atributos são relacionados à categoria ambiente $(62,60 \%)$ e organização (36,04\%), sendo alguns de social $(1,36 \%)$.

Constatou-se na amostra que certos atributos coletados não se enquadravam com os fatores de habitabilidade, os quais foram tratados como "Itens diversos" e que revelam anseios de cunho organizacional de empresa (ex.: comida melhor, fornecer roupa de cama, fornecer objetos para entretenimento, etc) e de valores estéticos (ex.: agradável, caprichado, aconchegante, etc.). Ou ainda, indicando aspectos socioculturais como no caso dos ambientes instalação sanitária e de vestiário em que houve menções sobre o aspecto de privacidade, emergindo a proposta de uso de um anteparo (barreira física) no acesso ao ambiente como instrumento de garantia de maior sensação de conforto interno no uso desses espaços.

O total de atributos relacionado aos fatores de habitabilidade distribuído por ambiente de área de vivência foram de 120 apontamentos (Quadro 03), sendo o fator 
mais recorrente é de "Funcionalidade e Acessibilidade" (47,50\%), seguido de "Saúde, Higiene e Qualidade do Ar" $(9,17 \%)$. O segundo item mais frequente é de "Itens diversos" (21,67\%), em que se enquadram atributos não-associáveis aos fatores de habitabilidade da NBR 15.575/2013, tais como: privacidade, boa comida, estética, etc. Em todos os 7 ambientes analisados prevaleceu o fator "Funcionalidade e Acessibilidade". Do contrário, o fator com menor apontamentos foi o "Desempenho Acústico" $(2,5 \%)$, sendo em alguns ambientes sequer citado.

\begin{tabular}{|c|c|c|c|c|c|c|c|c|c|}
\hline \multirow{2}{*}{$\begin{array}{l}\text { Fatores de } \\
\text { Habitabilidade da } \\
\text { NR 15575/2013. }\end{array}$} & \multicolumn{7}{|c|}{ Ambientes da Área de Vivência } & \multirow{2}{*}{$\begin{array}{l}\text { Soma } \\
\text { total }\end{array}$} & \multirow[t]{2}{*}{ (\%) } \\
\hline & Alojamento & $\begin{array}{l}\text { Área de } \\
\text { Lazer }\end{array}$ & Cozinha & $\begin{array}{l}\text { Inst. } \\
\text { Sanitária }\end{array}$ & Lavanderia & Refeitório & Vestiário & & \\
\hline $\begin{array}{l}\text { Funcionalidade e } \\
\text { acessibilidade }\end{array}$ & 9 & 5 & 9 & 15 & 3 & 8 & 8 & 57 & $47,50 \%$ \\
\hline Itens diversos & 2 & 5 & 1 & 3 & 2 & 7 & 6 & 26 & $21,67 \%$ \\
\hline $\begin{array}{l}\text { Saúde, higiene e } \\
\text { qualidade do ar }\end{array}$ & 2 & 1 & 2 & 1 & 1 & 2 & 2 & 11 & $9,17 \%$ \\
\hline Estanqueidade & 0 & 0 & 2 & 1 & 0 & 2 & 2 & 7 & $5,83 \%$ \\
\hline Desempenho térmico & 2 & 0 & 1 & 1 & 0 & 1 & 2 & 7 & $5,83 \%$ \\
\hline Desempenho lumínico & 1 & 0 & 1 & 0 & 1 & 1 & 1 & 5 & $4,17 \%$ \\
\hline $\begin{array}{l}\text { Conforto tátil e } \\
\text { antropodinâmico }\end{array}$ & 0 & 0 & 0 & 0 & 3 & 0 & 1 & 4 & $3,33 \%$ \\
\hline Desempenho acústico & 1 & 2 & 0 & 0 & 0 & 0 & 0 & 3 & $2,50 \%$ \\
\hline $\begin{array}{l}\text { Quantidade de apon- } \\
\text { tamentos verificados }\end{array}$ & 17 & 13 & 16 & 21 & 10 & 21 & 22 & 120 & $100 \%$ \\
\hline
\end{tabular}

Quadro 03 - Síntese de dados coletados sobre atributos do ambiente ideal para área de vivência associados aos fatores de habitabilidade da NRB 15.575(2013).

Fonte: Autores,2019.

No que se refere à associação dos dados às categorias de classificação "ambiente, organização ou social" (Figura 15), a análise do dados revela a prevalência da categoria ambiente (62,60\%), que trata de aspectos do ambiente construído. O espaço de vestiário foi o que obteve maior índice nessa categoria (71,73\%), seguido de instalação sanitária (71,73\%), refeitório $(66,67 \%)$ e do alojamento $(64,71 \%)$.

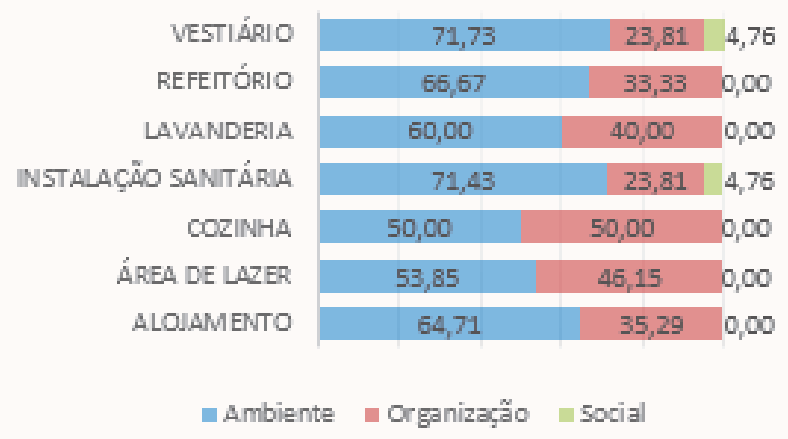

Figura 15 - Relação dos atributos coletados em categorias (\%) ambiente, organização e social. Fonte: Autores, 2019.

A categoria organização aparece em segundo lugar $(36,04 \%)$, cujo tema trata de aspectos de gestão e cultura organizacional da empresa. $\mathrm{O}$ ambiente da cozinha obteve o maior índice (50\%), seguido de área de lazer $(46,15 \%)$ e lavanderia (40\%). A categoria social (1,36\%), que trata de aspectos socioculturais e afetivos dos usuários, foi encontrada em apenas dois ambientes, instalação sanitária e vestiário, sendo ambos com o mesmo índice (4,76\%).

\subsection{Diagnóstico Ergonômico do Ambiente e Proposições}

\subsubsection{Ambiente Físico}

Em relação ao cumprimento da NR-18 sobre a área de vivência, foram verificadas situações de inadequação, como o dimensionamento de lavatório estar aquém do necessário (obra C); quantidade inadequada de banco nos vestiários (obras B e D); desrespeita o pé-direito mínimo para o refeitório ( obra C); requer instalar bebedouro no refeitório (obra D); e descumpre o dimensionamento mínimo da área de box individual de chuveiros e sem suporte instalado para sabonete e toalha (todas as obras).

No que se refere ao conforto lumínico, todas as obras precisam de ajustes, objetivando adequar a potência das lâmpadas para atingir o nível mínimo de 100 lux para vestiário e instalação sanitária, e de 150 lux para o refeitório, conforme NR-24 e NR-18.

Sobre a estanqueidade (controle de umidade e acesso de pontos de infiltração), a obra D apresenta problemas no teto do vestiário, com infiltração de água de chuva, e 
no teto do refeitório, cujos buracos nas telhas são originados pela queda de objetos em altura do bloco em construção próximo do local. Em ambos os ambientes há prejuízo no uso interno do local devido à grande proporção da infiltração de água pelo teto.

Acerca do conforto térmico e acústico, os ambientes apresentaram resultados dentro dos parâmetros normais das normas regulamentadoras (NR-15). Entretanto, devido à rotina penosa de atividades na construção civil, é comum os trabalhadores guardarem peças do vestuário de uniforme (ou roupas de trabalho) penduradas nas paredes ou acomodadas dentro dos armários individuais, bem como botinas/ calçados de segurança, sem higienização após a jornada de trabalho e com isso intensificando odores desagradáveis no local. Por isso, é interessante ajustar a estratégia de ventilação no ambiente para novas aberturas que permitam aumentar a circulação natural do ar e/ou instalar ventilação mecânica.

Quanto à funcionalidade e acessibilidade da área de vivência instalada, há conflito de entre o ambiente do vestiário $\mathrm{x}$ instalação sanitária na maioria das obras analisadas, devido à sua localizados em pontos distantes do terreno ou afastados da entrada da obra, induzindo o usuário a cruzar a circulação geral da obra para acessar um dos locais, em meio ao trânsito de maquinários e de solo lamacento/sem tratamento para circulação de pessoas.

Em se tratando de arranjo físico da obra, verifica-se que o layout da área de vivência é fragmentado, com grandes percursos a serem percorridos pelos usuários e sendo um dificultador da funcionalidade dos ambientes. Quando se analisa o layout interno dos ambientes, o local das instalações sanitárias apresenta conflitos por terem pouco espaço de circulação e ainda de esta acumular duas funções (de circulação e de área de mictório/lavatório), além de condições de falta de privacidade ao fazer uso do local.

\subsubsection{Ambiente Subjetivo}

Sobre a percepção do ambiente construído da área de vivência, observou-se que foi um exercício incomum para os usuário da amostra de avaliarem seus ambientes de trabaIho quanto às condições do ambiente construído da área de vivência. Verificou-se que na análise do ambiente real a amostra apresenta a característica de observações superficiais acerca do ambiente construído, não aprofundado em detalhes de cores, tecnologias construtivas, conforto, etc.

Em relação ao ambiente imaginário, a amostra mantém uma estreita associação mental entre a "organização do espaço", no sentido de gerenciamento do uso do espaço, e a "organização do ambiente construído", que se refere às características físicas/materiais do espaço a ser construído.
Ou seja, muitas vezes o público envolvido fez pouca diferenciação entre as sentenças acima, misturando nas suas respostas os atributos ambientais, organizacionais e sociais.

Ao se analisar as demandas dos usuários acerca do ambiente construído ideal sobre cada uma dos 7 ambientes da área de vivência, os dados obtidos se associam diretamente com o escopo de conteúdo de Fatores de Habitabilidade da NBR 15.575(2013), indicando a viabilidade de ser utilizado como um parâmetro técnico em avaliação do desempenho de edificações provisórias em área ade vivência de canteiros de obras.

Constataram-se vários atributos citados individualmente, tanto para o ambiente real quanto para o imaginário, de modo que esses dados possibilitam a reflexão das diversas escalas do programa de necessidades do projeto da área de vivência: da dimensão particularizada do usuário aos atributos de contexto coletivo e normativo.

Em relação aos atributos mais citados para ambiente real e imaginário (avaliação do usuário), após a comparação com os dados da avaliação do ambiente em uso (etapa 3 do MEAC), constata-se que há contradição entre os resultados da avaliação do usuário sobre o ambiente real e verificação da vistoria técnica, pois esta indica alguns pontos conflituosos nas condições do local (Figura 16) em relação às normas vigentes, à acessibilidade e funcionalidade, estanqueidade, ventilação e layout. Assim, emergem algumas proposições no sentido de reflexão para próximos empreendimentos: a) realizar o estudo de layout da área de vivência de modo a organizar os ambientes o mais próximo possíveis; b)considerar o uso de barreiras físicas para proporcionar privacidade de uso para os ambientes de vestiário e instalação sanitária; e c) estimular o exercício avaliativo do espaço de trabalho entre os trabalhadores da empresa, considerando temas direcionados ao ambiente construído da área de vivência.

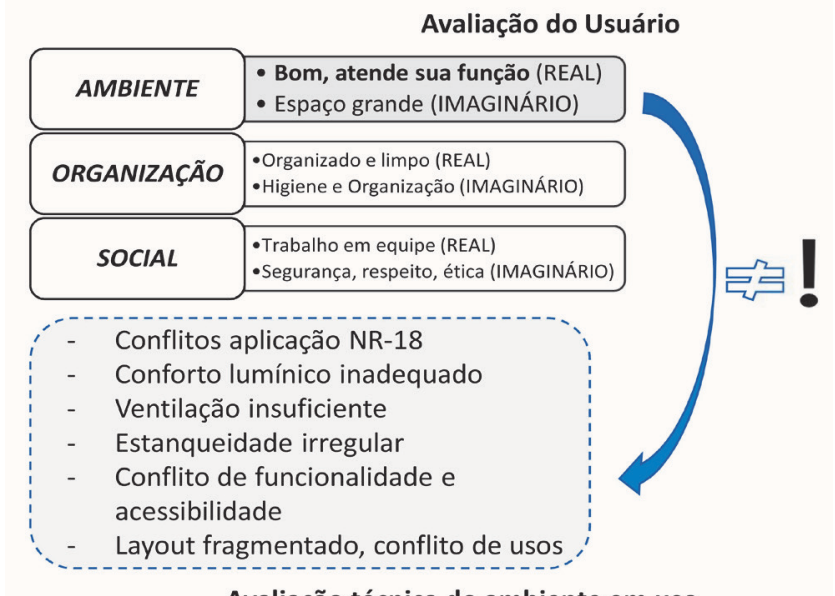

Avaliação técnica do ambiente em uso

Figura 16 - Relação dos atributos coletados em categorias (\%) ambiente, organização e social. Fonte: Autores, 2019 


\section{CONCLUSÃO}

A partir desta pesquisa, conhece-se o resultado da avaliação do ambiente construído pelo usuário do espaço da área de vivência em quatro obras da cidade de Criciúma/SC. Ao associá-lo aos fatores de habitabilidade da NBR15.575(2013), observou-se a possibilidade de ampliação desses fatores para edificações provisórias. Houve alguns pontos conflituosos em relação à norma vigente (NR-18), à acessibilidade e funcionalidade, estanqueidade, ventilação e layout. Constatou-se que o ambiente construído é percebido de modo superficial, ora de tímido julgamento crítico, ora pela atividade incomum de avaliar seu espaço de trabaIho numa obra. $\mathrm{O}$ dados encontrados indicam o cenário idealizado pelo usuário, revelando suas características de aspectos de funcionalidade, de uso e de apropriação do espaço construído, que auxiliarão projetistas no exercício de organização espacial da área de vivência em futuras obras.

Os dados levantados nesta pesquisa, fundamentado na NR-18 de 2019 e anterior a sua reformulação, poderão servir de base de dados para futuros estudos comparativos entre a percepção ambiental do usuário e as condições de ambiente construído das instalações da área de vivência considerando seus preceitos normativos antes e após a revisão da legislação.

\section{REFERÊNCIAS}

ASSOCIAÇÃO BRASILEIRA DE NORMAS TÉCNICAS. NBR- 12284: Áreas de Vivência em Canteiros de Obras. Rio de Janeiro, 1991.

_-. NBR 15575: Edificações habitacionais Desempenho. Partes 1 - 6. Rio de Janeiro, RJ, 2013

BRASIL. Portaria $\mathrm{n}^{\circ} \mathbf{3 . 2 1 4}$ do Ministério do Trabalho e Emprego de 08 de junho de 1978. Institui as Normas Regulamentadoras no Brasil. Disponível em < http://www.mte.gov.br/ legislacao/ portarias/1978/p_19780608_3214.pdf> Acesso em 28/10/2017.

."Reportagem “Nova NR 18 aumenta segurança dos trabalhadores e estimula modernização na construção civil"." Ministério do Trabalho. 2020. Disponível em: http://trabalho.gov.br/component/ content/article?id=7362. Acesso 11/02/2020.

DANIEL, T. C.; ITTELSON, W. H. Conditions for environmental perception research: Comment on" The psychological representation of molar physical environments" by Ward and Russell. 1981.

FABRICIO, M. M. Industrialização das construções: revisão e atualização de conceitos. Revista do Programa de Pós-Graduação em Arquitetura e
Urbanismo da FAUUSP, São Paulo, v. 20, n. 33, p. 228248, junho 2013.

FERREIRA, E. A. M.; FRANCO, L. S.. Metodologia para elaboração do projeto do canteiro de obras de edifícios. São Paulo, 1998.

FERRO, S.; ARANTES, P. F.. Arquitetura e trabalho livre. Editora Cosac Naify, 2006.

GREGOTTI, V.. Território da arquitetura. Perspectiva, 1972.

MONTANER, J. M.. Depois do movimento moderno: arquitetura da segunda metade do século XX. São Paulo: Gustavo Gili, 2014.

IBGE Instituto Brasileiro de Geografia e Estatística. Planilhada sobre pessoas de $\mathbf{1 4}$ anos ou mais de idade ocupadas na Construção. Disponível em:<http://www. cbicdados.com.br/menu/emprego/pnad-ibge-arquivos-resultados-brasil>.Acesso 30/07/2019.

LAWSON, B.. The language of space. Oxford: Architectural Press. 2001.

MATTOS, A. D.. Como preparar orçamentos de obra. São Paulo: Editora Pini, 2006.

MELHADO, S. B. Qualidade do projeto na construção de edifícios: aplicação ao caso das empresas de incorporação e construção. Tese (Doutorado). Departamento de Engenharia de construção de edifícios da Escola Politécnica da Universidade de São Paulo, São Paulo.1994

MORENO, L. D.; MAMEDE, B. B. Gestão da construção de edifícios no ambiente urbano: considerações sobre consequências e desdobramentos. Revista Nacional de Gerenciamento de Cidades, v. 1, n. 6, 2014. OKAMOTO, J.. Percepção ambiental e comportamento. $2^{\circ}$ Edição. IPSIS Gráfica e Editora S/A, São Paulo, 2002.

ROSSO, T. Racionalização da construção. São Paulo: Editora FAAUSP, 1980.

SAURIN, T. A., FORMOSO, C.T.Planejamento de canteiros de obra e gestão de processos. (Recomendações Técnicas HABITARE, v. 3. Porto Alegre : ANTAC, 2006.

TEZEL, B. A., KOSKELA, L. J., \& TZORTZOPOULOS, P. Visual management in construction: Study report on Brazilian cases. 2010.

TISAKA, M.. Como evitar prejuízos em obras de construção civil: Construction Claim. São Paulo: Pini, 2011a.

_-.Orçamento na construção civil: consultoria, projeto e execução. São Paulo: Pini, 2011b.

VILLA, S. B., ORNSTEIN, S. W. Qualidade ambiental na habitação: avaliação pós-ocupação. 2013. 
VILLAROUCO, V.. Construindo uma Metodologia de Avaliação Ergonômica do Ambiente - AVEA. Anais do $14^{\circ}$ Congresso Brasileiro de Ergonomia. Porto Seguro: ABERGO, 2008.

MONT'ALVÃO, C.; VILLAROUCO, V.. Um novo olhar para o projeto: a ergonomia no ambiente construído. Rio de Janeiro: 2AB, 2011.

\section{AUTORES}

ORCID: https://orcid.org/0000-0002-7395-6404

HELOISA NUNES E SILVA, M.Sc. | Doutoranda no PósARQ/ UFSC, Mestra em Arquitetura e Urbanismo, Engenheira de Segurança do Trabalho, Arquiteta e Urbanista | Universidade Federal de Santa Catarina | Programa de Pós-Graduação em Arquitetura e Urbanismo- PósARQ | Florianópolis, SC - Brasil | Correspondência para: Rodovia, SC-443, 845 - Vila Rica, Criciúma - SC, 88813-600 | E-mail: heloisa.nunes@ifsc.edu.br

ORCID: https://orcid.org/0000-0002-6784-8415

JUAN ANTONIO ZAPATEl PEREIRA DE ARAÚJO | Pós-Doutorado em Arquitetura e Urbanismo, Arquiteto e Urbanista. Universidade Federal de Santa Catarina | Programa de Pós-Graduação em Arquitetura e Urbanismo- PósARQ | Florianópolis, SC - Brasil | Correspondência para: Campus UFSC - Trindade , PósARQ/CTC Caixa Postal 476, Florianópolis - SC, 88040-900 | E-mail: juan.antonio@ ufsc.br

\section{COMO CITAR ESTE ARTIGO}

SILVA, Heloisa Nunes e; ARAÚJO, Juan Antonio Zapatel Pereira de. Arquitetura em Área de Vivência: Fatores Normativos Associados À Percepção do Usuário. MIX Sustentável, [S.I.], v. 6, n. 3, p. 129-146, jun. 2020. ISSN 24473073. Disponível em:<http://www.nexos. ufsc.br/index.php/mixsustentavel>. Acesso em: dia mês. ano. doi:https://doi.org/10.29183/2447-3073. MIX2020.v6.n3.129-146.

DATA DE ENVIO: 19/12/2019

DATA DE ACEITE: 29/05/2020 